\title{
Od wielkich odkryć po White Fleet. Diaspora portugalska w świecie i przedemigracyjne kontakty Portugalczyków z Kanadą
}

Portugalczycy to bez wątpienia najwięksi w dziejach odkrywcy i podróżnicy. Od XV do XVII wieku panowali na oceanach świata, ale będąc małym krajem bardzo szybko przegrywali walkę o wpływy na większości nowo odkrytych obszarów z mocniejszymi od siebie potęgami europejskimi.

Na przełomie XV/XVI wieku portugalskie żaglowce dotarły do wybrzeży dzisiejszej Brazylii i ta, na ponad trzy wieki, stała się perłą w koronie portugalskich posiadłości zamorskich. Tam też, przez wieki, najczęściej emigrowali Portugalczycy.

Wyjeżdżali oni jednak nie tylko do swoich kolonii. Portugalia prawie nigdy nie była dostatnim krajem dla większości jej mieszkańców. Od końca XIX wieku do lat 90. wieku XX z kraju wyjechało około 4 mln osób. Według statystyk w 2007 roku poza krajem przebywało niemal 5 mln Portugalczyków. Najwięcej w obu Amerykach 2,8 mln, w Europie diaspora portugalska liczyła w 2007 roku niemal 1,6 mln osób.

Portugalczycy nie tylko migrują po świecie, oni są także znakomitymi rybakami, którzy przez ponad 500 lat łowili na Grand Banks, u północno-zachodnich wybrzeży dzisiejszej Kanady. W XX wieku ich obecność na łowiskach wschodniokanadyjskich była zdominowana przez działalność tzw. White Fleet, Frota Branca.

Słowa kluczowe: Portugalczycy, odkrywcy, emigracja, rybacy, Biała Flota

${ }^{1}$ Kontakt: marta.kijewska-trembecka@uj.edu.pl 


\section{From the Age of Discovery to White Fleet: Portuguese Diaspora in the World and Portuguese Pre-Emigration Contacts with Canada}

The Portuguese are undoubtedly the greatest explorers and travelers in history. From the 15 th to the 17th century, they ruled the world's oceans, but being a small country they quickly lost their struggle for influence in most newly discovered areas to stronger European powers.

At the turn of the 15th and 16th centuries, Portuguese sailing ships reached the coast of today's Brazil, which for over three centuries became the pearl in the crown of Portuguese overseas possessions for centuries. It was also Brazil where the Portuguese emigrated most often.

However, they were leaving not only to their colonies. Portugal almost never was a prosperous country for most of its inhabitants. In the period of 100 years, from the end of the 19th century to the 1990s, about 4 million people left the country. According to statistics, in 2007, almost 5 million Portuguese lived outside their country. The largest number of them lived in the Americas - 2.8 million, while across Europe the Portuguese Diaspora in 2007 was as large as almost 1.6 million people.

Not only do the Portuguese migrate around the world, but they are also intrepid fishermen who fished for over 500 years on the Grand Banks, on the north-western coast of today's Canada. In the 20th century, their presence in the East Canadian fisheries was dominated by the so-called White Fleet, Frota Branca

Keywords: Portuguese, explorers, emigration, fishermen, White Fleet

\section{Portugalczycy w świecie}

Portugalczycy to bez wątpienia najwięksi w dziejach odkrywcy i podróżnicy, mecenasi wypraw jak Henryk Żeglarz ${ }^{2}$ i nieustraszeni żeglarze formatu Bartolomeo Diaza, Gaspara Corte-Reala, Fernando Magellana czy najważniejszego dla Portugalczyków - Vasco da Gamy. Od XV do XVII wieku panowali na oceanach świata, a gdy popatrzy się na mapę portugalskich odkryć, choćby tą wbudowaną w nabrzeże w pobliżu Torre de Belem w Lizbonie, skąd przed wiekami wypływali w nieznane, to dokładnie widać, że jako pierwsi dotarli do niemal wszystkich zakątków świata. Ale będąc małym krajem bardzo szybko przegrywali walkę o wpływy na większości nowo odkrytych obszarów z mocniejszymi od siebie potęgami w Europie i na morzu: Hiszpanią, Anglią czy Francją. Portugalscy żeglarze to także rybacy, którzy w poszukiwaniu łowisk penetrowali niemal cały północny Atlantyk, aż po jego zachodnie wybrzeża. Wielu badaczy uważa, choć nie wszyscy się z tym w pełni zgadzają ${ }^{3}$, że

${ }^{2}$ Henryk Żeglarz (Dom Henrique o Navegador, 1394-1460), infant portugalski, założył pierwszą w świecie szkołę nawigacji w Sagres, protektor i mecenas wypraw zamorskich, wielki zwolennik chrystianizacji nowo odkrytych ziem. Zapoczątkował handel niewolnikami z Afryki. https://encyklopedia.pwn.pl/haslo/Henryk-Zeglarz (2018-02-16)

${ }^{3}$ Dyskutowano o tym między innymi na konferencji Heritages and Memories from the Sea, w Evora, w styczniu 2015 roku, a referaty na niej wygłoszone ukazały się w: Themudo Barata, Filipe, Magalhaes Rocha, Joao, 2015, Conference Proceedings, University of Evora, Electronic editio; de Oliveira Marques, A.H., 1987, Historia Portugalii, tom I, Warszawa: PWN, s. 205-206. 
Luzytanie $^{4}$ już w średniowieczu docierali do dzisiejszych wybrzeży Nowej Fundlandii, a z pewnością byli tam w połowie XV wieku, łowiąc dorsze na bogatych łowiskach tzw. Grand Banks oraz wieloryby ${ }^{5}$. Angielskie źródła mówią, że w latach 1480-1509 portugalscy nawigatorzy, zapewne po szkole w Sagres, towarzyszyli także morskim wyprawom z Bristolu'

Na przełomie XV/XVI wieku portugalskie żaglowce dotarły do wybrzeży dzisiejszej Brazyliiं ${ }^{7}$, i ta, na ponad trzy wieki, stała się perłą w koronie portugalskich posiadłości zamorskich, co przekładało się także na płynące przez kilka wieków kolejne fale emigrantów z Portugalii do Brazyliii ${ }^{8}$. Już w XVI wieku do Brazylii wyjeżdżało z Portugalii około 3 tys. osób rocznie, w latach 70. XVI wieku mieszkało tam ponad 50 tys. imigrantów z metropolii a na początku XVII wieku już niemal 200 tys. Portugalczyków. Kolejna duża fala wyjazdów do Brazylii miała miejsce w II połowie XIX wieku, gdy rozwijały się wielkie plantacje brazylijskiej kawy i bawełny, a na mocy tzw. Złotego Prawa, Lei Aurea, w 1888 roku ostatecznie zniesiono niewolnictwo. Wg Walaszka w latach 1888-1939 do Brazylii wyjechało około 1,1mln Portugalczyków, a tylko w latach 1880-1900 prawie 400 tysięcy. Portugalczycy jechali tam do pracy, nierzadko sezonowej, ci wyjeżdżając wczesną

${ }^{4}$ Luzytanie to nazwa wywodząca się od antycznego ludu Luzytów zamieszkującego zachodnią i południowo-zachodnią część Półwyspu Iberyjskiego, od wieków nazwa ta odnosi się do Portugalczyków. Luzytanie są bohaterami najważniejszego portugalskiego eposu narodowego Os Lusiadas, Luisa Vaz de Camõesa. Epos opublikowany w 1572 roku opowiada historię narodu portugalskiego od starożytności po czasy wypraw do Nowego Świata. W szczególności przedstawia dokonania słynnych portugalskich żeglarzy i odkrywców, królów i rycerzy szerzących wiarę chrześcijańską na nowo odkrytych ziemiach. Kanwą dla eposu jest słynna wyprawa Vasco da Gamy do Indii 1497-99. Najnowszego, znakomitego przekładu na język polski dokonał Ireneusz Kania. Luzytanie w jego przekładzie ukazali się nakładem Wydawnictwa Literackiego w 1995 roku.

${ }^{5}$ de Oliveira Marques, A.H., 1987, Historia Portugalii, tom I, Warszawa: PWN, s. 138-139, 205206. Marques da Silva, A.J., 2015, The Fable of the Code and the Promised Sea. About Portuguese traditions of bacalhau, w: Temudo Barata, Magalhaes Rocha, 2015, s. 130-144; Anderson, G.M., Higgs, D., 1976, A Future to Inherit. The Portuguese Communities of Canada, Toronto: McClelland and Stewart, s. $5-10$.

${ }^{6}$ Rayburn, A.., 1994, Naming Canada. Stories about Place Names from Canadian Geographic, Toronto: University of Toronto Press, s. 87-94; Anderson, Higgs, 1976, s. 7.

${ }^{7}$ Oficjalnie odkryta w 1500 roku przez Pedro Alvares Cabrala, ale wg historyków już wcześniej Portugalczycy wiedzieli o jej istnieniu jednak zastosowali blef dzięki któremu traktat z Tordesillas z 1494 roku wyznaczył linię dzielącą obszary odkryć i eksploatacji nowych ziem między Kastylię i Portugalię na południku oddalonym od Wysp Zielonego Przylądka o 1184 mile a nie o 320 jak zabiegała u papieża Aleksandra VI Kastylia. Hermano Saraiva, J, 2000, Krotka historia Portugalii, Kraków: Universitas, s. 200-207.

${ }^{8}$ Brazylia była tak ważna dla Lizbony, że w okresie napoleońskiego kryzysu w Europie, w pierwszych dekadach XIX wieku, cały dwór portugalski, większość arystokracji, urzędników wyższego strzebla, i de facto wszyscy inni, którzy mogli, około 10 tys. ludzi, wyjechali do Brazylii w 1808 roku i przez 13 lat tam próbowali zbudować nowe imperium. Rio było wówczas stolicą Portugalii (de Oliveira Marques, 1987, t. II, s. 80-87). 
jesienią wracali najczęściej w maju․ Brazylia była zawsze celem najliczniejszych ich pozaeuropejskich migracji ${ }^{10}$.

Nie tylko Brazylia, niemal każde odkrycie nowych ziem skutkowało migracjami doń. Budowa fortu, jego obrona, administrowanie, rozwój handlu, który był główną formą relacji metropolii z koloniami, sprzyjały mniej lub bardziej licznemu osadnictwu. Portugalczycy więc nie tylko żeglowali aby odkrywać, odbywali też wiele podróży aby osiedlać się, czy tylko czasowo mieszkać, w coraz to nowych miejscach na różnych kontynentach.

Głównym celem XV. wiecznych portugalskich wypraw było znalezienie morskiej drogi do Indii, ale nim dokonał tego podczas wyprawy w latach 1497-99 Vasco da Gama, inni, niejako o drodze, odkrywali kolejne ziemie. Odkrycie wysp na Atlantyku: Madery, Azorów, Wysp Zielonego Przylądka (Cabo Verde), oraz dotarcie do terenów dzisiejszej Angoli, miało dla Portugalii dalekosiężne skutki ${ }^{11}$. Luzytanie osiedlili się tam i pozostali na wieki. Angola i Cabo Verde uzyskały niepodległość od metropolii dopiero w połowie lat 70. XX wieku, a Madera i Azory są dziś autonomicznymi regionami wchodzącymi w skład Portugalii.

Portugalczycy wyjeżdżali jednak nie tylko do swoich kolonii lub byłych kolonii. Portugalia nigdy nie była dostatnim krajem dla większości jej mieszkańców. „ Głód, bieda, życiowa opresja i ciągła niepewność życiowa" pchała ich do wyjazdu. Szukając lepszego życia emigrowali „za chlebem” tam gdzie mieli nadzieję na lepsze życie. W okresie stu lat, od końca XIX wieku do lat 90. wieku XX, z Portugalii wyjechało około $4 \mathrm{mln}$ ludzi ${ }^{12}$. Należy tu pamiętać o wielkości społeczeństwa portugalskiego. W początkach XX wieku Portugalia liczyła około 6 mln mieszkańców, w latach 30. XX wieku niespełna $7 \mathrm{mln}$, w roku $19508,5 \mathrm{mln}$, w $19608,9 \mathrm{mln}, 19708,6 \mathrm{mln}$, 1980 9,8 a w 2001 w Portugalii mieszkało 10,3 mln osób ${ }^{13}$. Dwie największe fale emigracyjne miały miejsce w latach 1911-1913 (i kilku następnych) i od roku 1953 do końca lat 70. W pierwszym okresie, tylko w ciągu tych trzech lat, wyjechało

9 Walaszek, A., 2007, Migracje Europejczyków 1650-1914, Kraków: Wydawnictwo Uniwersytetu Jagiellońskiego, s. 243-244. Szerzej o migracjach Portugalczyków od epoki odkryć geograficznych do pierwszych dziesięcioleci XX wieku można znaleźć w: Walaszek, A., 2013, Dwie europejskie peryferie: porównanie migracji portugalskich i polskich od XVI wieku do Wielkiej Wojny, „Studia Migracyjne Przegląd Polonijny", 39(2013), nr 2, s. 15-50.

${ }_{10}$ Rocha-Trindade M.B., 2009, The Portuguese Diaspora, w: Teixeira C., da Rosa V.M.P., 2009, The Portuguese in Canada. Diasporic Challenges and Adjustment, Toronto: University of Toronto Press, s. 20-22.

11 Odkrycia: Medera 1418; Azory 1427; Cabo Verde 1462, Angola, 1483. Angola w XVI, ale w szczególności w XVII i XVIII wieku była podstawowym „dostarczycielem” niewolników do Brazylii i do Ameryki Północnej. Pod koniec XVII wieku rocznie było to około 7,5 ludzi, a sto lat później już dwa razy więcej. de Oliveira Marques, 1987, t.II, s. 88-97; Rocha-Trindade, 2009, s. 21-22.

12 Teixeira, C., da Rosa, V.M.P., 2009, A historical and Geographical Perspective, w: Teixeira, da Rosa, 2009, s. 4.

${ }^{13}$ Instituto Nacional de Estatistica. Statistics Portugal; https://www.ine.pt/xportal/xmain?xpid=INE\&xpgid=ine_base_dados. (2018-02-25) de Oliveira Marques, 1987, t. II, s. 246, 259-260. 
ponad 225 tys. ludzi, czyli około 3,5\% ogółu ludności kraju, oni pojechali przede wszystkim do Brazylii. Druga fala była jeszcze większa. W latach 50. wyjeżdżało średnio rocznie około 30 tys. osób, a od początku lat 60. emigrowali jeszcze liczniej. W samym 1965 roku wyjechało 89 tys., w następnym 120 tys., a w 1967 roku 95 tys. osób. W sumie $\mathrm{w}$ tym okresie wyemigrowało $\mathrm{z}$ kraju ponad 1,5 mln Portugalczyków, szósta część jego mieszkańców. Wyjeżdżali za Ocean, do Brazylii, USA i Kanady, ale przede wszystkim były to migracje europejskie. Do Francji i Niemiec trafiło ponad $1 \mathrm{mln}$ osób. Wyjazdom otwarcie sprzyjał reżim Salazara ${ }^{14}$.

Emigracja z Portugalii ma jeszcze jeden istotny wymiar, mianowicie jest mocno zróżnicowana $\mathrm{w}$ zależności od regionu, $\mathrm{z}$ którego się wywodzi. Portugalia to tzw. kontynent i wyspy. Dziś wyspy to Azory i Madera, ale do lat 70. XX wieku liczyły się jeszcze Wyspy Zielonego Przylądka, które należały do Portugalii w okresie od 1462 do 1975 roku. Wyspy, z przyjmujących w okresie kolonizacji, od końca XIX wieku stały się wysyłającymi emigrantów. W XX wieku mieszkańcy Madery i Cabo Verde jechali przede wszystkim do Brazylii i do kolonii w Afryce - Angoli i Mozambiku oraz do pracy w południowoafrykańskich kopalniach. Ale ostatnim dziesięcioleciu XIX wieku z Madery kilka tysięcy wyjechało na Wyspy Sandwich, dzisiejsze Hawaje. Co ciekawe pojechali za nimi pierwsi emigranci z bardzo biednej środkowej portugalskiej prowincji Alentejo. W wyniku suszy, która jeszcze bardziej pogorszyła stan rolnictwa $w$ tej prowincji, w latach 1910-1911 zdecydowało się na wyjazd z Alentejo około tysiąca rolników. Należy pamiętać, że w taką podróż nie wybierali się najbiedniejsi ${ }^{15}$. W połowie XX wieku z Madery, oraz północno-zachodniej części Portugalii kontynentalnej, z Aveiro, emigrowano do Wenezueli. Z kolei emigracja z Azorów tradycyjnie kierowała się głównie do Ameryki Północnej, preferowano USA. Pod koniec XIX wieku Azorczycy jechali tam jako rybacy i marynarze, gdy się osiedlali pracowali w kopalniach i stoczniach, przy budowie kolei, na farmach. W Kalifornii rekrutowano ich do połowów wielorybów i pracy na farmach w żyznych kalifornijskich dolinach.

Dla Portugalczyków emigracja do USA, ale także Kanady, nie była łatwa nie tylko z powodów finansowo-logistycznych, ale także z ważnej innej przyczyny. Długo, niemal do lat 50. XX wieku, nie byli oni uznawani za rasę czysto białą a za tzw. pośrednią, pomiędzy białą a kolorową, nazywani byli także oil-skinned. W związku $\mathrm{z}$ taką kategoryzacją podlegali ograniczeniom wjazdowym do obu krajów ${ }^{16}$. W latach 60. XX wieku Portugalczycy, w szczególności z Azorów, łatwiej mogli osiedlić się w USA na mocy the Azorean Refugee Act, wydanego w 1958 roku. Prawo to

${ }^{14}$ de Oliveira Marques, 1987, t. II, s. 360; Rocha-Trindade, 2009, s. 26-27.

15 Ibidem, s. 21, 37.

16 Znakomitą analizę rasistowskiego podejścia anglosaskiego świata wobec Portugalczyków przedstawił w swoim artykule Robert F. Harney, Portygees and Other Caucasians. Portuguese Migrants and Rasism of the English-speaking World w: Higgs, D., ed., 1990, Portuguese Migration in Global Perspective Toronto: The Multicultural History Society of Ontario, s. 113-135. 
zostało przyjęte, $z$ inicjatywy ówczesnego senatora Massachusetts J.F Kennedy’ego, po wybuchu wulkanu Capelinhos na azorskiej wyspie Faial, który był aktywny w latach 1957-58. Na początku lat 60. do Ameryki jechało rocznie około 10-12 tys. Portugalczyków, w większości właśnie z Azorów. Później średnia roczna wynosiła 2 do 3 tys. osób. Te ułatwienia były z pewnością jednym z czynników sprzyjających emigracji do USA ${ }^{17}$.

Z kolei emigrację europejską wybierali przede wszystkim mieszkańcy kontynentalnej Portugalii, często z obszarów metropolitalnych - Lizbony i Porto. Od lat 60. XX wieku Europa Zachodnia była „głodna niewykwalifikowanych robotników"18. Portugalczycy jechali przede wszystkim do Francji, Niemiec, na Wyspy Brytyjskie, do Szwajcarii, Holandii i Belgii. Wiele zmieniło się w portugalskich migracjach po Europie gdy w 1986 roku Portugalia przystąpiła do Unii Europejskiej /wówczas EWG/. Od rej pory Portugalczycy w UE z emigrantów ekonomicznych stali się rezydentami. Do końca XX wieku najwięcej Portugalczyków wybrało Francję, tu w latach 90. mieszkało ich ponad milion, na drugim miejscu plasowały się Niemcy, ponad 100 tys. ${ }^{19}$. Ciekawym przykładem jest Luxemburg. W kraju liczącym, w 2007 roku, około 550 tys. mieszkańców, diaspora portugalska stanowiła niemal 15\% jego społeczeństwa, około 70 tys. osób, co więcej było to ponad 30\% luksemburskich pracowników, mniej lub bardziej wykwalifikowanych ${ }^{20}$. Można powiedzieć, że to największe zagęszczenie Portugalczyków poza Portugalią.

Według portugalskich statystyk, w 2007 roku poza krajem przebywało niemal $5 \mathrm{mln}$ Portugalczyków. Najwięcej w obu Amerykach 2,8 mln - w USA ponad 1,3 mln, w Brazylii około 700 tys., w Wenezueli niespełna 400 tys. W Europie diaspora portugalska liczyła w 2007 roku niemal 1,6 mln osób, najwięcej we Francji około 800 tys., dalej w Wielkiej Brytanii prawie 250 tys., w Szwajcarii ponad 180 tys. i Niemczech 115 tys. W Afryce mieszkało wówczas ponad 375 tys. osób, w dawnych koloniach: Mozambiku 13 tys., w Angoli niemal 45 tys. Najwięcej natomiast w RPA, niemal 300 tys. osób, ${ }^{21}$ to przede wszystkim ci, którzy po uzyskaniu niepodległości przez kolonie portugalskie w Afryce nie wyjechali do metropolii a przenieśli się do rządzonej wówczas jeszcze przez białych Afryki Południowej. Wielu jechało tam celem „przeczekania czasowego zamieszania” w koloniach, ale zostali na wiele lat.

Trzeba podkreślić, że w przypadku Portugalczyków, szczególnie gdy wyjeżdżali poza Europę, niemal zawsze była to emigracja łańcuchowa: rodzinna, sąsiedzka, regionalna. W mniejszym stopniu dotyczyło to migracji europejskich.

\footnotetext{
17 Rocha-Trindade, 2009, s. 24-25.

18 Ibidem, s. 27.

${ }^{19}$ Ibidem, s. 26-29.

${ }^{20}$ http://www.statistiques.public.lu/en/index.html (2018-02-25)

${ }^{21}$ https://www.portugal.gov.pt/pt/gc21,Ministry of Foreign Affairs, Portugal 2007 (2018-02-25)
} 
W latach 70. XX wieku Portugalia, prócz wielu innych problemów do rozwiązania, musiała poradzić sobie z falą migracji powrotnych. Po upadku dyktatury Salazara przyjęła setki tysięcy powracających z kolonii rodaków retornados. Nie było to łatwe dla bardzo biednego wówczas kraju. Oficjalne dane mówią o co najmniej 500 tys. osób, a wg nieoficjalnych, liczących także nielegalnych przybyszów, to niemal 800 tys. co stanowiło prawie $8 \%$ populacji Portugalii. Ponad $60 \% \mathrm{z}$ nich przyjechało z Angoli, dalsze 33\% z Mozambiku, reszta z innych kolonii, które doczekały się niezależności od Lizbony. Powracający stanowili ogromny problem dla młodej republiki. Kraj nie był w stanie zapewnić im godziwych warunków, dlatego jedynie część z powracających została w Portugalii a znaczny odsetek, od razu lub w ciągu kilku lat, ruszył dalej ${ }^{22}$.

W końcu XX wieku, dzięki reformom wewnętrznym i funduszom unijnym, w Portugalii znacznie podniósł się poziom życia przeciętnego mieszkańca. W pierwszych latach XXI wieku zaczęli i tu przyjeżdżać imigranci, w szczególności z krajów luzofońskich. Wg danych służb portugalskich w 2006 roku w Portugalii mieszkało niemal 440 tys. obcokrajowców, $32 \%$ z nich pochodziło z byłych portugalskich kolonii w Afryce, w tym ponad 65 tys. z Wysp Zielonego Przylądka. Kolejne 15\% stanowili Brazylijczycy, około 65 tys., a prócz tych legalnie przebywających, w Portugalii nielegalnie osiedliło się ponad 40 tys. Brazylijczyków ${ }^{23}$.

W ciągu ostatnich dwóch dekad Portugalia stała się także celem migracji z różnych krajów unijnych, z tzw. starej Unii: Brytyjczyków, Niemców, Francuzów, Hiszpanów. Ci kupują domy wraz z gajami oliwnymi, winnicami czy nawet, w Alentejo, lasami dębów korkowych i żyją wygodnie grzejąc się w portugalskim słońcu. Osiedlają się też rezydenci z nowych unijnych krajów, najwięcej przybyszy jest z Rumunii. W Portugalii dość chętnie mieszkają także Amerykanie. Diaspora polska w tym kraju jest nieliczna, to mniej niż 1,5 tys. osób. W sumie osoby z wymienionych wyżej krajów stanowią nieco ponad $20 \%$ obcokrajowców mieszkających w Portugalii. Nowością jest imigracja z Ukrainy, Mołdowii i Rosji, to kolejne niemal $10 \%$ przyjezdnych ${ }^{24}$.

Kryzys 2008, który bardzo drastycznie dotknął portugalską gospodarkę, w szczególności młodych, wśród których bezrobocie sięgało ponad $40 \%{ }^{25}$, przyniósł następną, najnowszą falę emigracji z Portugalii. Jak podają badacze The Emigration Observatory - OEm Instituto de Ciências Sociais da Universidade de Lisboa (ICS-UL) w okresie od 2008 do 2015 roku z Portugalii wyjechało niemal 2 mln, głównie młodych ludzi, piąta część społeczeństwa tego kraju. Wyjechali do

22 Rocha-Trindade, 2009, s. 30-32.

23 Ibidem, s. 32-33.

${ }^{24}$ Ibidem, s. 33-34; http://www.lizbona.msz.gov.pl/pl/aktualnosci/polonia_portugalii (201802-25)

${ }^{25}$ https://www.iscte-iul.pt/conteudos/research/observatories/1032/observatories (2018-02-25); http://observatorioemigracao.pt/np4EN/paises.html (2018-02-25) 
innych krajów UE - Wielkiej Brytanii, Niemiec, Francji, ale też do USA i np. Mozambiku, którego gospodarka nieźle się rozwijała i potrzebowała wykształconych specjalistów. W roku 2007 w Mozambiku mieszkało około 4,2 tys. Portugalczyków a w 2013 ponad 24 tys. $^{26}$.

\section{Kontakty z Kanadą. Bacalhau na północno-zachodnim Atlantyku}

Jak wspomniano wyżej, kontakty Luzytan z obszarami dzisiejszej Kanady datują się z pewnością na XV i XVI wiek, choć niektórzy uważają, że Portugalczycy docierali do wybrzeży obecnej Nowej Fundlandii i Labradoru już w XIII i XIV wieku i wraz z baskijskimi rybakami łowili dorsze w wodach Grand Banks ${ }^{27}$. Przez wieki dorsze, bacalhau, były podstawą portugalskiej diety, także, a może przede wszystkim, ubogiej ludności wiejskiej. Suszone, częściej solone i suszone, ze względu na swe właściwości odżywcze nazywane były o fiel amigo, wiernymi przyjaciółmi ${ }^{28}$. Przez wieki Portugalczycy wyprawiali się po dorsze na wody północno-zachodniego Atlantyku.

W wyprawie Johna Cabota do Nowego Świata w 1497 roku uczestniczył portugalski nawigator Joao Fernandes zwany a lavrador, jest on pierwszym Potrugalczykiem, którego obecność w Nowym Świecie jest udokumentowana. Pochodził z Terceiry na Azorach. Nazwa Labrador pochodzi od jego przezwiska ${ }^{29}$. Kontakty handlowo-morskie Portugalczyków z Bristolem były dość częste już od XIV i ich wspólne wyprawy morskie nie były rzadkością. Podobnie Portugalczycy żeglowali na północny i zachodni Atlantyk wspólnie z Duńczykami, w tym przypadku, w XV wieku, oba kraje łączyły królewskie mariaże ${ }^{30}$.

26 http://observatorioemigracao.pt/np4EN/paises.html?id=158 (2018-02-26)

27 Mówią o tym między innymi teksty prezentowane na konferencji Heritages and Memories from the Sea, Evora, 14-16 January 2015, zawarte w : Themudo Barata, Filipe, Magalhaes Rocha, Joao, 2015, Conference Proceedings, University of Evora, Electronic edition. I prawdopodobnie od Basków nauczyli się konserwacji dorszy solą, której dość bogate złoża znajdują się w Portugalii. Portugalczycy handlowali także solą dostarczając ją np. Anglikom na łowiska Grand Banks, ibidem s. 19-39. Anderson, Higgs, 1976, s. 10-11.

${ }^{28}$ Praca kanadyjskiego historyka $\mathrm{z}$ University of Toronto H.A. Innisa, The Cod Fisheries: The History of an International Economy,1940, New Haven: Yale University Press, jest uznawana za klasyczne dzieło mówiące o skomplikowanej historii i wadze połowów dorsza u wschodnich wybrzeży dzisiejszej Kanady dla rozwoju kolonializmu w ogóle.

${ }^{29}$ lavrador, znaczy rolnik/farmer czasem robotnik rolny. Rayburn, 1994, s. 88. Inne źródła mówią, że Joao Fernandes już wcześniej odwiedził te ziemie. Anderson, Higgs, 1976, s. 5-6.

30 Anderson, Higgs, 1976, s. 6-8. Tu może warto przytoczyć dwie informacje czy raczej ciekawostki - poloniki z tamtego okresu, obie niepotwierdzone. Pierwsza mówi o Janie z Kolna/ Johannesie: Scolvus, Skolus, Szkolnym/ nawigatorze w służbie żeglugi duńskiej (norweskiej?), który miał dotrzeć do dzisiejszego Labradoru, już w 1476 roku. http://www.biographi.ca/en/bio/scolvus_john_1E.html (2018-03-12).

Druga, to opowieść, legenda z portugalskiej Madery. Mówi o polskim królu, który nie zginął w bitwie na południowym wschodzie Europy a uszedł z życiem i dzięki zaufanym koneksjom po- 
W latach 1500-1501 kolejne wyprawy wysłane przez Manuela I, króla Portugalii, a dowodzone przez, pochodzących także z azorskiej Terceiry, Gaspara Corte-Reala i jego brata Miguela, dotarły do Grenlandii i dalej do wschodnich wybrzeży obecnej Kanady. W St. John's stolicy Nowej Fundlandii stoi, ufundowany przez organizacje portugalskich rybaków, pomnik Gaspara Corte-Reala. Napis na tablicy mówi, nie tylko o przybyciu Corte-Reala do Terra Nova, ale także o wielu wiekach kontaktów i przyjacielskich relacji między rybakami z Portugalii a mieszkańcami Nowej Fundlandii ${ }^{31}$.

Wiele nazw na wschodnim kanadyjskim wybrzeżu ma portugalskie źródła, choć dziś często funkcjonują w wersjach angielskich, na przykład Cabo de Sao Jorge (Cape St. George), Ilha Roxa (Red Island) czy Cape Rose (Cabo Raso, ostatni punkt na lądzie, gdy Tagiem wypływa się z Lizbony). Portugalskim odkrywcom przypisywane są także nazwy Nowa Fundlandia (Terra Nova) oraz Rzeka św. Wawrzyńca (Baia de sa Lourenco), odkryta prawdopodobnie w dniu św. Wawrzyńca ${ }^{32}$.

Są dowody na to, że już na początku XVI wieku portugalscy rybacy, głównie z Azorów i Aveiro, łowili na Grand Banks. Obszary te, na mapach z tamtego okresu, nazywane są Tierra Nueva de los Bacallaos ${ }^{33}$. Jak pisze de Oliveira Marques było to regularne łowienie „zorganizowano floty, ustalono cła i regulaminy dla handlu dorszami”"34. Widząc wielkie profity, jakie przynosiły połowy na Grand Banks w imieniu króla Manuela I pobierano cła od przywiezionych dorszy w portach na Duoro i Minho oraz w Aveiro.

Około 1550 roku z samego regionu Aveiro, wypłynęło po dorsze na Grand Banks około 150 żaglowców. Portugalczycy łowili wówczas głównie w rejonie Półwyspu Avalon, w południowo-wschodniej części wyspy Nowa Fundlandia. Tam też leży najstarsza osada na wyspie - Portugal Cove oraz największe miasto-port Nowej Fundlandii St. John's ${ }^{35}$.

tajemnie osiadł, wraz z innymi uciekinierami, na portugalskiej Maderze. Królem tym miałby być Władysław III Warneńczyk, a bitwa pod Warną z 1444 roku. Po przybyciu na Maderę miał przyjąć imię Henrique Alemao i zamieszkać w posiadłości Madalena do Mar, którą miał podarować mu sam Henryk Żeglarz. Tam ożenił się i miał syna, zginął na morzu w wieku czterdziestu kilku lat. Jedna z wersji tej legendy mówi, że jego synem był sam Vasco da Gama (urodzony w latach 60., najczęściej podawane są daty:1460 lub 1469), czemu oczywiście gorąco zaprzeczają Portugalczycy, ale badania genetyczne nie bardzo mogą ruszyć z miejsca.

${ }^{31}$ https://www.yelp.ca/biz/gaspar-corte-real-monument-st-johns (2018-02-24)

32 Teixeira, da Rosa, 2009, s 6; de Oliveira Marques, 1987, t. I, s. 138; The Canadian Family Tree. Canada's People, 1979, Don Mills: Multiculturalism Directorate, s. 180-181; Rayburn, 1994, s. 89-90.

${ }^{33}$ Grand Banks to grupa podwodnych plateau u południowo-wschodnich wybrzeży Nowej Fundlandii, gdzie zimny Prąd Labradorski miesza się z ciepłym Golfsztromem. Znajdują się tam najbogatsze na świecie łowiska, szczególnie dorodnych dorszy. https://www.britannica.com/place/ Grand-Banks, (2018-02-24); Doel, P.A., 2009, The White Fleet and the Iconography of Control, w: Texeira, da rosa, 2009 , s. 45.

34 de Oliveira Marques, 1987, t. I, s. 258.

35 Anderson, Higgs, 1976, s. 10-11; Portugal Cove znaczy portugalska zatoczka. 
Na wody zachodniego Atlantyku Portugalczycy wyprawiali się jeszcze do końca XVI wieku i sporadycznie do połowy następnego stulecia. Przez kolejne prawie dwa wieki polityczne zawirowania w Europie i skomplikowane relacje Portugalii z Hiszpanią i Madrytu z Anglią, wykluczyły portugalskich rybaków z połowów u północno-zachodnich wybrzeży Atlantyku. Wówczas zaopatrywali się w dorsze $\mathrm{w}$ portach angielskich handlując w zamian oliwą, winem, solą, a przede wszystkim czarnymi niewolnikami. Na Grand Banks powrócili, na krótko, w połowie XIX wieku, a na dobre z początkiem XX wieku i byli tam obecni przez ponad kolejnych siedem dekad ${ }^{36}$.

\section{Era White Fleet ${ }^{37}$}

W XX wieku Portugalczycy łowili na Grand Banks przez większość stulecia. Ich obecność na łowiskach wschodniokanadyjskich była zdominowana przez działalność tzw. White Fleet, Frota Branca. Jednak powrót na zachodni i północny Atlantyk wiązał się z nowymi wyzwaniami, którym Portugalscy rybacy nie zawsze mogli sprostać. Wieki wcześniej dominowali nad innymi swoimi znakomitymi umiejętnościami żeglarskimi, znajomością morza i odwagą w konfrontacji w żywiołami. Tym zdobywali przewagę także nad konkurencją innych, rosnących w siłę potęg morskich. Ale w XX wieku te umiejętności już nie wystarczyły. Portugalia, niebogaty kraj na krańcu Europy, nie była w stanie nadążyć za technologicznymi udoskonaleniami jakimi inne kraje wyposażały swoje flotylle połowowe. Dziś można powiedzieć, że portugalscy rybacy łowili bardziej ekologicznie, w sposób przyjazny środowisku morskiemu, ale sto lat temu tak nie myślano. Konkurencja na wodach Grand Banks powoli, ale skutecznie wypierała tych, którzy kiedyś byli tam najmocniejsi. Jednak ciągle pozostali ludzie, luzytańscy rybacy, gotowi na bardzo ciężką pracę, którzy jak przed wiekami byli na morzu znakomici, i to przede wszystkim ich praca pozwoliła portugalskim statkom na obecność na wodach wokół północno-wschodnich wybrzeży Kanady. Za czasów Salazara warunki pracy na portugalskich statkach były niewiele lepsze od tych sprzed stuleci. Racjonowanie słodkiej wody, brak sanitariatów i godziwych warunków odpoczynku był na statkach Białej Floty codziennością. Zarobki też były marne, ale siedmioletnia praca na takich fregatach dawała zwolnienie z obowiązku pójścia do wojska, co niechybnie oznaczało wysłanie do Afryki. Zaokrętowanie się na trawlerze, na Grand Banks

${ }^{36}$ Ibidem, s. 11-13. Doel, P..A., Andrieux, J-P, Collins, P., 2009, Newfoundland and the White Fleet, w: Teixeira, da Rosa, 2009, s. 44-80; Margues da Silva, 2015, s. 130-143.

37 Ta portugalska flotylla statków połowowych nie ma nic wspólnego z tzw. Great White Fleet, czyli armadą amerykańskich pancerników, które prezydent Roosvelt wysłał, w latach 1907-1909, w propagandowy rejs dookoła świata, który miał pokazać potęgę amerykańskiej marynarki wojennej. 
pływało ich kilka pod portugalską banderą, nie dawało takiego zwolnienia bo było „mniej patriotyczne” niż targanie się na szkunerach ${ }^{38}$.

Unowocześnianie rybołówstwa to także nowe metody konserwacji ryb, to przede wszystkim różne sposoby ich zamrażania. Tu portugalscy rybacy, jako jedni z nielicznych, stosowali nadal przede wszystkim tradycyjne metody solenia i suszenia bacalhau. Tym samym rynek odbiorców ich ryb skurczył się niemal wyłącznie do portugalskich konsumentów. Ten bardzo stary sposób konserwacji połowu niekoniecznie był wynikiem tak mocnego przywiązania do tradycji, ale przede wszystkim braku możliwości, i finansowych, i technologicznych portugalskich firm połowowych. Reżim Salazara wykorzystał to i włączył solenie bacalhau do oficjalnej propagandy, uznając solonego dorsza za jeden $\mathrm{z}$ ważnych elementów identyfikacji narodowej Portugalczyków. Program ten znany jest pod nazwą bacalhau campanha ${ }^{39}$.

Do dziś, mocno solony dorsz to ryba dostępna w Portugalii na każdym kroku a można go przygotować, według Portugalczyków, na 365 sposobów.

W latach 1903-1914 na wodach Grand Banks operowały nawet 34 portugalskie statki, bacalhoeiros. Portugalczycy łowili także w czasie I wojny, a w 1922 roku było tam już 65 portugalskich szkunerów, na każdym z nich znajdowało się kilkadziesiąt małych połowowych łódek. Po proklamowaniu przez Salazara Estado Novo ${ }^{40} \mathrm{w} 1933$ roku połowy dorszy na wodach zachodniego i północnego Atlantyku zostały włączone w system państwa korporacyjnego i szczegółowo podporządkowane kontroli rządowej. Rząd częściowo unowocześnił flotyllę bacalhoeiros ale równocześnie uznał tradycyjne metody konserwacji dorszy poprzez solenie niemal za narodowy priorytet i tylko nieliczne trawlery przetwórnie towarzyszyły wyprawom na Grand Banks. Równocześnie znacznie zwiększyła się ilość rybaków wysyłanych na łowiska, przebywali na nich, wahadłowo, po kilka miesięcy, pracując w niezwykle ciężkich warunkach. W latach 30. rocznie nawet 6 tys. Portugalczyków łowiło u wybrzeży Kanady, a w 1941 roku około 3 tys. ${ }^{41}$. W latach 20. na wodach Atlantyku, w pobliżu St.John's, pojawił się pierwszy portugalski statek szpital dla rybaków, Carvalho Araujo, zastąpiony wkrótce innym, tzw. pierwszym, Gil Eannes ${ }^{42}$

38 Andrieux, 2009, s. 68.

${ }^{39}$ Marques da Silva, 2015, s. 135.

40 António de Oliveira Salazar rządził w latach 1932-68 (zmarł w 1970), ale rządy reżimu trwały do 1974, do tzw. rewolucji goździków, Revolução dos Cravos. Estado Novo, Nowe Państwo, proklamowane w 1933 roku to korporacyjny model państwa autorytarnego, mocno konserwatywnego, ściśle powiązanego z bardzo tradycyjnym Kościołem katolickim. Cztery dekady rządów ekipy Salazara sprawiły, że Portugalia „stała się zapyziałym krajem na peryferiach Europy” jak obrazowo określany jest efekt rządów Salazara, a społeczeństwo portugalskie, jeszcze w latach 70. miało najwyższy stopień analfabetyzmu w całej Europie. W 1940 roku analfabetami było 55\% społeczeństwa Portugalii, w 1950 45\%, a w 1968 roku ponad 30\%. W latach 50. obowiązek szkolny wynosił 3 lata, a w latach 1960-67 4 lata. de Oliveira Marques, 1987, t. II, s. 362.

${ }^{41}$ Anderson, Higgs, 1976, s. 13.

${ }^{42}$ Gill Eanes / Gilianes Eannes / to XV. wieczny portugalski podróżniki odkrywca. https://web.archive. org/web/20070208175217/http://www.win.tue.nl/ engels/discovery/eannes.html (dostęp: 2018-02-26) 
(Eanes). Przez całe wieki, portem gdzie portugalscy rybacy schodzili na ląd był właśnie St. John's.

Określenie Biała Flota, pochodzi z okresu II wojny światowej, kiedy Portugalczycy, zachowując oficjalną neutralność, przemierzali Atlantyk udając się na połowy na Grand Banks. Początkowo pływali w kilka jednostek ale po zatopieniu przez niemieckie wojska dwóch statków, mimo umowy z Niemcami, że portugalscy rybacy nie będą atakowani, ocean przemierzali tzw. milczącymi konwojami. Statki miały burty wymalowane na biało, na nich widniały wielkie nazwy jednostek a na pokładach powiewały białe flagi ${ }^{43}$. Stąd White Fleet. Po wojnie kolor biały pozostawiono.

Czasy powojenne, do mniej więcej II połowy lat 60., nazywane są złotym okresem Białej Floty na Grand Banks. Każdego lata tysiące portugalskich rybaków przypływało na te łowiska, a cała flota cumowała w St. John's. Portugalczycy byli zaprzyjaźnieni z mieszkańcami portu, a gdy w 1949 roku Nowa Fundlandia przyłączyła do Federacji Kanadyjskiej jako dziesiąta prowincja, relacje stały się jeszcze cieplejsze. White Fleet była najliczniejszą armadą zatrzymującą się w porcie St. John's. Dla Portugalczyków, niezwykle ciężko pracujących na przestarzałych, w stosunku do innych flot, statkach, a do tego pochodzących z bardzo biednego kraju, wielu z nich było Azorczykami a tam było jeszcze biedniej, wyjście na ulice kanadyjskiego miasta (miasteczka) było nie lada atrakcją ${ }^{44}$. Jednak mimo możliwości, do rzadkości należało pozostanie rybaków w Kanadzie. Niemal wszyscy wracali do kraju.

Okres ten to także mocna propaganda reżimu Salazara, która uzasadniała taką a nie inną portugalską politykę morską. W połowie lat 50 . Salazar rozkręcił międzynarodową kampanię dumnie propagującą obchody 500 lat portugalskich odkryć w Nowym Świecie i niemal tyluż obecności luzofońskich rybaków na wodach Grand Banks. Jednym z głównych wydarzeń tej kampanii było wodowanie nowego statku, jak głosiła propaganda „zbudowanego w portugalskim porcie, $\mathrm{z}$ rodzimych materiałów, przez portugalskich szkutników i rzemieślników, jako majestatycznego symbolu portugalskiej obecności na wodach Grand Banks w przeszłości, obecnie i w przyszłości”" ${ }^{3}$. Nową jednostkę nazwano ponownie Gil Eanes (II). Mogła zabrać

${ }^{43}$ Zdarzyło się jednak, że na Gil Eanes nalazł się radiotelegrafista pracujący na rzecz Niemców, Gastao de Freitas Ferraz, który informując Niemców o ruchach alianckiej floty na Atlantyku, niemal doprowadził do porażki Operation Torch w trakcie Kampanii Północno-Afrykańskiej jesienią 1942 roku. Gil Eanes został namierzony przez brytyjski HMS Duke of York a radiotelegrafista aresztowany. Evans, Michael Declassified MI5 file shows Nazi spy almost changed course of war. (Times Online, March 3, 2009).

${ }^{44}$ Pracowali bardzo ciężko, obowiązywała zasada: jeden rybak, jedna łódź, co oznaczało, że każdy miał małą łódkę na fregacie i po prostu spuszczany na wodę łowił „na rękę" wrzucając dorsze do swojej łódki, a potem, po połowie, widłami (!) na główny pokład. Wokół każdej fregaty roiło się od łódek „łupinek”. Filmy z lat 60. XX wieku robią wstrząsające wrażenie. https://www.youtube.com/ watch?v=-zpMPmhPdWI

https://www.youtube.com/watch?v=FW5FGQfdTU4

https://www.youtube.com/watch?v=R4ivTjzhM5Q

45 Doel, 2009, s. 50. 
do pięciu tysięcy portugalskich i azorskich rybaków i przetransportować na drugi brzeg Atlantyku, gdzie czekała na nich Biała Flota.

Nowy Gil Eanes miał symbolizować najważniejsze wartości Estado Novo: Boga/ kościól, państwo i rodzinę (deus, patria, familia), o czym mówiły dwa epickie murale zdobiące wnętrze Gil Eanes, azorskiego artysty Domingos Rebelo ${ }^{46}$.

Jednostka ta przeznaczona była do wielu zadań, prócz szpitala i kaplicy, służyła de facto jako centrum kontroli, według zasad korporacyjnego państwa Salazara, portugalskich marynarzy i rybaków na wodach u wybrzeży wschodniej Kanady. Kapitan tej fregaty był oficjalnie zwierzchnikiem wszystkich portugalskich statków łowiących na wodach północno-zachodniego Atlantyku, a dodatkowo funkcjonariuszem Estado Novo.

Aż do połowy lat 50. XX wieku rybacy łowiący na przybrzeżnych wodach Nowej Fundlandii byli niemal jedynymi Portugalczykami, z którymi mieli kontakt Kanadyjczycy. Jak wspomniano wyżej mieszkańcy St. John’s nawiązali bardzo ciepłe relacje z rybakami Białej Floty, choć ci niemal w ogóle nie mówili po angielsku. Lubili ich kolorowe stroje, głośne rozmowy, serdeczność w kontaktach i melancholijne śpiewy przy gitarach. Nauczyli się od nich grać w piłkę nożną, która w wolne dni była główną rozrywką Portugalczyków na nabrzeżach portu w St. John's. Za zarobione pieniądze rybacy kupowali towary niedostępne w Portugalii, więc pełno było ich w sklepach miasteczka. Wieczory spędzali w tawernach pijąc, najczęściej przywiezione portugalskie wino, w które zaopatrywali także bary w St. John's, i zabawiając się z dziewczynami przy tęsknym fado śpiewanym przez kompanów ${ }^{47}$. Korzystali z przyjemności tak innego od ich portugalskiego czy azorskiego świata.

Jedną z ważnych uroczystości związanych z jubileuszem pięciu wieków obecności Luzytan na zachodnim Atlantyku było ofiarowanie przez Portugalczyków figury Matki Boskiej Fatimskiej, poświęconej w Fatimie, Bazylice w St. John's. Ceremonia była bardzo uroczysta. 27 maja 1955 roku niemal 4 tysiące kolorowo ubranych portugalskich rybaków maszerowało ramię w ramię ulicami St. John’s niosąc ponad metrowej wysokości postać Matki Boskiej Fatimskiej jako dowód wdzięczności i przyjaźni wobec mieszkańców Nowej Fundlandii za ich wielowiekowe goszczenie Portugalczyków. „Evening Telegram” miejski dziennik pisał wówczas „Sześć tysięcy ludzi, którzy wypełnili katedrę, wraz z tymi, którzy stali wzdłuż ulic miasta, było jednym $z$ najbardziej kolorowych, inspirujących i uroczystych wydarzeń jakie kiedykolwiek miały miejsce w St. John's"48. Figura stoi do dziś po lewej stronie głównego ołtarza Bazyliki pod wezwaniem św. Jana Chrzciciela.

${ }^{46}$ Dziś do oglądnięcia w Muzeum Morza w Belem w Lizbonie.

47 Collins, 2009, s. 81-82.

48 „Evening Telegram” (St. John's), 27 May, 1955, https://www.library.mun.ca/cns/webresources/ digitized (2018-02-24) 


\section{Saudade i minha terra}

Przez wieki portugalscy rybacy wypływali w morze, w podróż pełną niebezpieczeństw, i na kilka miesięcy opuszczali rodzinę, dom, ciepło swojej ziemi. Za pozostawioną minha terra ${ }^{49}$ tęsknili nie tylko oni, uczucie rozdzielenia zawsze towarzyszyło żeglarzom i odkrywcom, udającym się w nieznane, ale także tym, którzy jechali zasiedlać nowoodkryte ziemie, do Brazylii, na Goa, czy Mozambi$\mathrm{ku}$, i tam pozostawali50. To także tęsknota tych, którzy zostali w domu i niepokój czy bliscy szczęśliwie wrócą. Mówi się, że gdy stanie się na portugalskim brzegu Atlantyku saudade przychodzi samo. Saudade to pewna kategoria melancholii, to rodzaj portugalskiej więzi z przeszłością, to wobec niepewnej przyszłości tęsknota za tym co było. Za rodziną, za kochanką zostawioną w St. John's, za nieobliczalnym, bezkresnym oceanem, za czasami, gdy Portugalia królowała na morzach, a Portugalczycy byli największymi odkrywcami. Kabowerdyjskie saudade (sodade) przywołuje XIX. wieczne, przymusowe przesiedlenia z Wysp Zielonego Przylądka do Afryki i gorycz niewolnictwa. Saudade to wreszcie opowieść o mitycznym kraju i jego mieszkańcach, bohaterach eposu Luisa Vaz de Camõesa Os Lusiadas. Salman Rushdie napisał kiedyś, że „przeszłość jest krainą, z której wszyscy wyemigrowaliśmy" ${ }^{\prime 1}$. Te słowa w szczególności odnoszą się Portugalczyków.

Saudade jest jedną z wartości uznanych za element portugalskiego dziedzictwa narodowego, tak było w epoce de Camõesa, wieki później za czasów twórczości Fernando Pessoa, czy współcześnie gdy tęskne kabowerdyjskie sodade śpiewała w swoich pieśniach (mornas) Cesaria Evora, a na kontynencie Amalia Rodrigues czy wielka współczesna diva fado, urodzona w Mozambiku, Mariza. Mariza to wyjątkowa interpretatorka tekstu Cavaleiro Monge F. Pessoa, a wraz z Tito Paris, najbardziej bodaj po C. Evorze znanym kabowerdyjskim artyście, śpiewa słynne Beijo de Saudade ${ }^{52}$. Saudade rybaków z Białej Floty jest jedną z egzemplifikacji tego portugalskiego fenomenu.

49 Znaczenie zwrotu minha terra jest najbliższe temu co Ossowski nazwał ojczyzną prywatną. Ossowski, St., 1984, Analiza socjologiczna pojęcia ojczyzny, w: O ojczyźnie i narodzie, Warszawa: PWN, s. 21-27.

${ }^{50}$ Collins, Peter, 2009, Remembering the Portuguese, w: Teixeira, da Rosa, 2009, s. 77-88.

51 "The past is the country from which we have all emigrated". Rushdie, S., 1991, Imaginary Homelands: Essays and Criticism 1981-1991, London: Granta Books, s. 12.

${ }^{52}$ Muzyka fado ma dość skomplikowaną historię i powiązania. Jej ojczyzną jest bardziej Brazylia niż Portugalia, ale tu, szczególnie w XX wieku, rozwinęła się niezależnie od swej oryginalnej wersji. Przez długi okres czasu była muzyką biednych dzielnic i portowych tawern Lizbony, Porto czy barów i ulicy Coimbry. Salazar wciągnął fado do swojej propagandy Nowego Państwa. Wraz z demokratyzacją Portugalii została na nowo odkryta, bary i kluby fado, szczególnie te na lizbońskiej Alfamie, są nie tylko turystycznymi atrakcjami. Tu toczy się prawdziwe portugalskie życie, niezależne od tego, co przyszło z zewnątrz, choćby na przykład w Mesa de Frades. Świetną historię fado napisał Rui Vieira Nery, Para uma Historia do Fado, pierwsze wydanie rok 2004. Po polsku Historia fado wyszła w 2015 roku nakładem wydawnictwa Replika. 


\section{Epilog}

W 1964 roku Kanada poszerzyła swoje tereny połowowe z trzech do dwunastu mil przybrzeżnych, co znacznie ograniczało możliwości połowowe Portugalczyków. Równocześnie przyszła mocna rywalizacja ze strony lepiej wyposażonych, bardziej nowoczesnych flotyll rybackich z innych krajów, także tych dotąd niemal nieobecnych na wodach północno-zachodniego Atlantyku. Wśród nich, obok Japonii, ZSRR i NRD, była także Polska. Biała Flota przynosiła coraz mniejsze profity. We wrześniu 1965 roku, w czasie pobytu w St.John’s z okazji odsłonięcia pomnika Gaspara Corte-Reala, ambasador Portugalii w Kanadzie w swym przemówieniu wspomniał o zbliżającym się końcu pięćsetletniej obecności portugalskich rybaków $\mathrm{w}$ tym regionie świata ${ }^{53}$. Koniec ten nastąpił szybciej niż spodziewali się rybacy Białej Floty. Właściciele fregat zawierali „umowy dżentelmeńskie” z ubezpieczycielami i rządem Portugalii i w ciągu kilku lat większość statków łowiących u wybrzeży Nowej Fundlandii szła na dno w konsekwencji pożarów, które najczęściej wywołane były kontrolowanymi wybuchami w maszynowni. Rybacy wiedzieli, że ich fregata zatonie i było to dla nich ogromnie dramatyczne doświadczenie. Gil EanEs transportował ich do portu St. John's, a potem, wszystkich, do Portugalii ${ }^{54}$. Z początkiem 1974 roku ogień strawił jedne z ostatnich fregat White Fleet. Do 25 kwietnia 1974 roku, do Rewolucji Goździków, dotrwały trzy. Dwie z nich spłonęły w czerwcu tego roku na wodach Grand Banks, a ostatnia Novos Mares w lipcu 1974 roku wyruszyła z kanadyjskich wybrzeży w swoją ostatnią podróż przez Atlantyk do macierzystego portu w Aveiro ${ }^{55}$. Ten rejs zakończył niemal pięć wieków obecności portugalskich rybaków u północno-wschodnich wybrzeży dzisiejszej Kanady. Pozostały wspomnienia kilku wieków serdecznych kontaktów między portugalskimi rybakami a mieszkańcami St. John's.

Relacje portugalsko-kanadyjskie nie zostały jednak przerwane, druga połowa XX wieku to początek nowych związków, które w latach 50. i 60. zapoczątkowane zostały przez pierwsze $\mathrm{w}$ dziejach kanadyjskiej imigracji grupy luzofońskich emigrantów.

\section{Bibliografia}

Anderson, G. M., Higgs, D. (1976), A Future to Inherit. The Portuguese Communities of Canada, Toronto: McClelland and Stewart

Armando O. M., (2009), Azorean Diaspora and Cultural Retention in Montreal and Toronto, w: Teixeria, da Rosa, 2009, s. 91-108.

Collins P. (2009), Remembering the Portuguese, w: Teixeira, da Rosa, 2009, s. 77-88.

\footnotetext{
${ }^{53}$ Andrieux, J.P., 2009, Portuguese Fishermen in Newfoundland, w : Teixeira, da Rosa, 2009, s. 69.

${ }^{54}$ Ibidem, s. 70-71.

55 Doel, 2009, s. 57-58.
} 
da Rosa V., Teixeira C. (2000), The Portuguese in Canada: from the sea to the city, Toronto: University of Toronto Press.

de Oliveira Marques A. H. (1987), Historia Portugalii, tom I i t. II, Warszawa: PWN.

Harney R. F. (1990), Portygees and Other Caucasians. Portuguese Migrants and Racism of the English-speaking World w: D. Higgs, (ed.), Portuguese Migration in Global Perspective Toronto: The Multicultural History Society of Ontario, s. 113-135.

Hermano S. J. (2000), Krótka historia Portugalii, Kraków: Universitas.

Higgs D. (1982), The Portuguese in Canada, Ottawa: The Canadian Historical Association.

Higgs D. (1990) (ed.), Portuguese Migration in Global Perspective Toronto: The Multicultural History Society of Ontario

Innis H. A. (1940), The Cod Fisheries: The History of an International Economy, New Haven: Yale University Press.

Marques da Silva, A. J. (2015), The Fable of the Code and the Promised Sea. About Portuguese traditions of bacalhau, w: Temudo Barata, Magalhaes Rocha, 2015, s. 130-144.

Ossowski S. (1984), Analiza socjologiczna pojęcia ojczyzny, w: O ojczyźnie i narodzie, Warszawa: PWN.

Rashdie S. (1991), Imaginary Homelands: Essays and Criticism 1981-1991, London: Granta Books.

Rayburn A. (1994), Naming Canada. Stories about Place Names from Canadian Geographic, Toronto: University of Toronto Press.

Rocha-Trindade M. B. (2009), The Portuguese Diaspora, w: Teixeira C., da Rosa, 2009, s. 18-41.

Teixeira C., da Rosa V. (2009), A historical and Geographical Perspective, w: Teixeitra, da Rosa, 2009, s. 3-17.

Teixeira C., da Rosa V. (2009), The Portuguese in Canada. Diasporic Challenges and Adjustment, Toronto: University of Toronto Press.

Teixeira C., Murdie R. C. (2009), On the Move. The Portuguese in Toronto, w: Teixeitra, da Rosa, 2009, s. 191-208.

The Canadian Family Tree. Canada's People, (1979), Don Mills: Multiculturalism Directorate.

Themudo Barata, F., Magalhaes Rocha J., (2015), Conference Proceedings; z konferencji Heritages and Memories from the Sea, Evora, 14-16 January 2015, University of Evora, Electronic edition.

Vaz de Camões L. (1995), Luzytanie, Kraków: Wydawnictwo Literackie.

Vieira Nery R. (2015), Historia Fado. Zakrzewo: Replika.

Walaszek A. (2007), Migracje Europejczyków 1650-1914, Kraków: Wydawnictwo Uniwersytetu Jagiellońskiego.

Walaszek A. (2013), Dwie europejskie peryferie: porównanie migracji portugalskich i polskich od XVI wieku do Wielkiej Wojny, „Studia Migracyjne - Przegląd Polonijny”, 39(2013), nr 2, s. $15-50$.

Evans M. (2009). Declassified MI5 file shows Nazi spy almost changed course of war. (Times Online, March 3, 2009) (2018-03-05)

„Evening Telegram” (St. John’s), 27 May, 1955 https://www.library.mun.ca/cns/webresources/ digitized (2018-03-05)

\section{Strony internetowe}

http://observatorioemigracao.pt/Canada

http://www.biographi.ca/en/bio/scolvus_john_1E.htm

http://www.lizbona.msz.gov.pl 
http://www.statcan.gc.ca

http://www.statistiques.public.lu

http://www.statistiques.public.lu/en/index.html

https://web.archive.org/web/20070208175217/http://www.win.tue.nl/ engels/discovery/eannes.html

https://www.iscte-iul.pt/conteudos/research/observatories/1032/observatories http://observatorioemigracao.pt/np4EN/paises.html

https://www.portugal.gov.pt/pt/gc21, Ministry of Foreign Affairs, Portugal 2007

https://www.yelp.ca/biz/gaspar-corte-real-monument-st-johns

https://www.youtube.com/watch?v=FW5FGQfdTU4

https://www.youtube.com/watch?v=R4ivTjzhM5Q

https://www.youtube.com/watch?v=-zpMPmhPdWI

Instituto Nacional de Estatistica. Statistics Portugal; https://www.ine.pt/xportal/xmain?xpid= $\underline{\text { INE\&xpgid=ine_base_dados }}$ 